\title{
0 uso de PCR na detecção de Escherichia coli enterotoxigênica em amostras de água de esgoto
}

\author{
Detection of enterotoxigenic Escherichia coli in sewage water samples by the PCR technique
}

\author{
Alessandra Mallmann Nascimento ${ }^{1} \&$ Sueli Teresinha Van Der Sand $d^{1,2}$
}

\begin{abstract}
RESUMO
Riscos à saúde, associados à transmissão de doenças através do meio aquático, tornam importante a detecção de microrganismos patogênicos nesse ambiente. Portanto, o objetivo deste trabalho foi utilizar a técnica de PCR para uma detecção rápida de Escherichia coli enterotoxigênica (ETEC) em água de esgoto. Com o propósito de isolar esta bactéria, as amostras de esgoto foram inoculadas no meio seletivo ágar eosina azul de metileno (EMB). As colônias isoladas foram identificadas através de testes bioquímicos e as $E$. coli encontradas foram submetidas à extração de DNA plasmideal por lise alcalina e posteriormente à reação de PCR. Desses isolados, 5 apresentaram resultado positivo: 3 isolados foram positivos para o gene da toxina LT e 2 isolados para os genes de ambas as toxinas. As condições utilizadas na reação de PCR não detectaram a presença de E. coli, quando aplicada diretamente nas amostras de esgoto. Os produtos de amplificação dos 5 isolados de $E$. coli foram digeridos com enzimas de restrição e os fragmentos resultantes confirmaram a especificidade da amplificação. Os resultados sugerem que a técnica de PCR reduz o tempo de detecção do microrganismo, porém a amostra necessita de um pré-enriquecimento para aumentar a sensibilidade da técnica.
\end{abstract}

Descritores: PCR, esgoto, Escherichia coli, plasmideo.

\section{ABSTRACT}

Health risks associated with waterborne transmission of diseases makes detection of pathogenic microorganisms critical in this environment. Therefore, the aim of this work was to use PCR assay for the rapid detection of enterotoxigenic Escherichia coli (ETEC) in sewage water. Therefore, with the purpose to isolate these bacteria, the samples of sewage water were inoculated in selective media eosin methylene blue agar (EMB). Biochemical testes were used to identify the isolated colonies and the E. coli found were submitted to extraction of the plasmid DNA by alkaline lise and used in the PCR reaction. Five isolates presented a positive result: three isolates were positive for LT toxin gene and two for both toxins (ST and LT). The amplification conditions used in PCR assay, when applied directly to sewage samples, did not detect the presence of the pathogenic E. coli. Amplification products of ETEC isolates were digested with restriction enzymes and the resulting fragments confirmed the specificity of the amplification. The results showed that PCR assay can reduce time detection however, the sample need an pre-enrichment cultivation in order to improve the sensibility of the technique, keeping the same amplification conditions.

Key words: PCR, sewage water, Escherichia coli, plasmid. 


\section{INTRODUÇÃO}

A Escherichia coli como parte da flora endógena do intestino, mantém uma relação de comensalismo com o hospedeiro. Esta relação pode modificarse quando a bactéria adquire elementos genéticos que codificam fatores de virulência causando doenças em humanos e animais. Os principais fatores de virulência da $E$. coli enterotoxigênica (ETEC) em diarréias são as enterotoxinas e as adesinas fimbriais $[1,4,30]$. A ETEC contém plasmídeos que codificam genes para as toxinas termo-lábil (LT) e termo-estável (ST) [5,8, 22,25] e é causadora de diarréia em regiões onde as condições de saneamento básico são precárias, sendo alta a sua incidência em crianças [10,16,18,21,25].

Escherichia coli enterotoxigênica (ETEC) associados à diarréia também causam morbidade e mortalidade em leitões. A diarréia em leitões desmamados, causada por ETEC, economicamente é uma das doenças mais importantes para a indústria de suínos.

A deteç̧ão de ETEC em ambientes aquáticos é importante, quando da ocorrência de surtos. A utilização de bioensaios clássicos permite identificar microrganismos fenotipicamente patogênicos. Porém, somente a análise do DNA revela o potencial genético para a produção de virulência [13].

A técnica de reação em cadeia da polimerase (PCR) pode ser altamente específica e sensível na detecção de microrganismos. A detecção de uma molécula de DNA é possível, porém a sensibilidade da reação continua sendo o maior problema associado ao método [5,6]. O sucesso do uso de PCR em amostras ambientais requer cuidados no processamento das amostras para remoção completa dos contaminantes que são os maiores responsáveis pela inibição e redução da sensibilidade da reação [25].

O objetivo deste estudo foi desenvolver um protocolo rápido e sensível para a detecção de $E$. coli enterotoxigênica em amostras de água de esgoto utilizando PCR.

\section{MATERIAIS E MÉTODOS}

\section{Coletas das amostras e isolamento microbiano}

Amostras de água de esgoto provenientes de diferentes locais de amostragem na cidade de Porto Alegre foram analisadas neste trabalho. As amostras foram coletadas em frascos estéreis de $250 \mathrm{~mL}$ e estes foram mantidos sob refrigeração até o momento de seu processamento. Cada amostra coletada sofreu uma diluição de $10^{-1} \mathrm{em}$ água peptonada $0,1 \%$. A diluição mais a amostra bruta foram semeadas, em triplicata, em meio seletivo agar eosina azul de metileno (EMBMERCK) para isolamento e diferenciação das colônias de E. coli. As placas foram incubadas por 24 horas a $37^{\circ} \mathrm{C}$ e as colônias típicas foram selecionadas e semeadas em meio caldo tripticaseína de soja (TSBOXOID) e incubados como descrito anteriormente. Após o crescimento as culturas foram semeadas em agar tripticaseína de soja (TSA-OXOID) para posterior identificação.

As amostras de esgoto também foram processadas através de filtração em membrana milipore 0,22 mm. A membrana foi então submersa em $10 \mathrm{~mL}$ de solução salina por 24 horas. Após a retirada da membrana as células foram submetidas à lise alcalina para extração do DNA plasmideal [18] e, posterior análise por PCR.

\section{Identificação da $E$. coli através de provas bioquímicas}

A partir do repique realizado em TSA os isolados foram submetidos aos seguintes testes bioquímicos para a identificação de E. coli: vermelho de metila (VM), Voges Proskauer (VP), SIM, citrato, lactose, glicose, produção de gás a partir da utilização de glicose, fenilalaninadesaminase, lisina, sorbitol e ramnose. A classificação do gênero e espécie foi baseada em MacFaddin [14].

\section{Reações de PCR}

Para os testes de padronização da técnica de PCR, foram utilizadas linhagens padrão de E. coli enterotoxigênicas: ATCC 11105 (ST+${ }^{+} \mathrm{LT}^{+}$), IAL 1895 (ST$\left.\mathrm{LT}^{+}\right)$, IAL $1878\left(\mathrm{ST}^{+} \mathrm{LT}^{-}\right)$. O DNA plasmideal foi extraído destas linhagens e, dos isolados positivos para E. coli identificados por bioquimismo, utilizando o método descrito por Sambrook et al. [19]. Os oligonucleotídos iniciadores foram desenhados a partir das sequiências completas dos genes ST [7] e LT [29]. STI: 5'- GTCTTTTTCACCTTTCGCTC - 3', localizado na posição 63 sense e STII 5' - TACAAGCAGGATTA CAACAC - 3', localizado na posição 229 anti-sense. LTI 5'- CGATGGCAGGCAAAAGAGAA - 3', localizado na posição 356 sense e LTII 5'- GTTTTCCATA CTGATTGCCG - 3', localizado na posição 576 antisense. As reações de amplificação foram realizadas em um volume final de $25 \mathrm{~mL}$. Para amplificação dos genes ST e LT foram utilizados: tampão de reação 1X (100mM Tris- $\mathrm{HCl}, 500 \mathrm{mM} \mathrm{KCl}, 2,5 \mathrm{mM} \mathrm{MgCl}$ -CENBIOT), 2,5 mM de deoxinucleotídeos (PHAR- 
MACIA), $100 \mathrm{ng}$ de soro albumina bovina (BSAPHARMACIA), 30 ng de cada oligonucleotídeo iniciador STI e STII (CYBERSYN BIODYNAMICS), 0,5 U da enzima Taq DNA polimerase (CENBIOT) e 30 ng de DNA plasmideal molde. As condições de amplificação estabelecidas para o gene ST foram: 1 ciclo inicial de $1 \mathrm{~min}$. a $95^{\circ} \mathrm{C}, 5 \mathrm{~min}$. a $60^{\circ} \mathrm{C}$ e $2 \mathrm{~min}$. a $72^{\circ} \mathrm{C}$, mais 35 ciclos de $45 \mathrm{seg}$. a $95^{\circ} \mathrm{C}, 45 \mathrm{seg}$. a $48^{\circ} \mathrm{C}$ e 90 seg. a $72^{\circ} \mathrm{C}$; para o gene LT: 1 ciclo inicial de $1 \mathrm{~min}$. a $95^{\circ} \mathrm{C}, 5 \mathrm{~min}$. a $60^{\circ} \mathrm{C}$ e $2 \mathrm{~min}$. a $72^{\circ} \mathrm{C}$, e 30 ciclos de $30 \mathrm{seg}$. a $95^{\circ} \mathrm{C}, 30 \mathrm{seg}$. a $61^{\circ} \mathrm{C}$ e $60 \mathrm{seg}$. a $72^{\circ} \mathrm{C}$.

\section{Teste de especificidade e sensibilidade dos oligonucleotídeos}

DNA plasmideal dos controles positivos ( $E$. coli (ETEC)) e o de outras bactérias padrão (controles negativos) (Tabela 1) foram utilzados para a valiar a especificidade dos pares de oligonucleotídeos iniciadores. Os DNA dos diferentes microrganismos

Tabela 1. Linhagens padrão utilizadas nos ensaios de especificidade da reação de PCR.

\begin{tabular}{ll}
\hline \multicolumn{1}{c}{ Linhagem } & \multicolumn{1}{c}{ Coleção } \\
\hline Escherichia coli Enterotoxigênica (ST+ LT+) & ${ }^{1}$ ATCC 11105 \\
Escherichia coli Enterotoxigênica (ST-LT+) & ${ }^{3}$ IAL 1895 \\
Escherichia coli Enterotoxigênica (ST+LT-) & ${ }^{3}$ IAL 1878 \\
Enterobacter aerogenes & ${ }^{1}$ ATCC 13048 \\
Enterobacter cloacae & ${ }^{2}$ INCQS 00146 \\
Klebsiella pneumoniae & ${ }^{1}$ ATCC 10031 \\
Listeria monocytogenes & ${ }^{2}$ INCQS 7644 \\
Proteus mirabilis & ${ }^{2}$ INCQS 0098 \\
Proteus vulgaris & ${ }^{2}$ INCQS 00106 \\
Pseudomonas aeruginosa & ${ }^{1}$ ATCC 25619 \\
Salmonella enteretidis & ${ }^{1}$ ATCC 13076 \\
Salmonella typhimurium & ${ }^{1}$ ATCC 14028 \\
Shigella dysenteri & ${ }^{3}$ IAL 1496 \\
Shigella flexneri & ${ }^{3}$ IAL 1541 \\
Shigella boydii & ${ }^{3}$ IAL 1548 \\
Shigella sonnei & ${ }^{1}$ ATCC 25931 \\
Vibrio cholerae & ${ }^{3}$ IAL 1941 \\
Yersinia enterocolitica & ${ }^{1}$ ATCC 9610 \\
\hline de Qualidade em Saúde (Fundação Osvaldo Cruz, Rio de Janeiro, \\
Brasil), ${ }^{3}$ Instituto Adolfo Lutz (São Paulo, Brasil). \\
\end{tabular}

foram amplificados utilizando as condições acima descritas.

A sensibilidade da técnica de PCR utilizandose os pares de oligonucleotídeos iniciadores para detecção de $E$. coli foi avaliada através do número de unidades formadoras de colônias (UFC/mL). Para esta análise, foi utilizada uma cultura de $E$. coli no final da fase exponencial de crescimento a qual sofreu diluições seriadas $\left(10^{-1}\right.$ a $\left.10^{-9}\right)$ em $9 \mathrm{~mL}$ de água peptonada $0,1 \%$. As diluições foram semeadas, em duplicata, em placas contendo meio TSA e o restante do volume foi submetido a extração de DNA plasmideal. A sensibilidade, quanto a concentração de DNA, também foi testada através de diluições seriadas do DNA plasmideal extraído dos microrganismos padrões.

\section{Digestão com enzima de restrição dos produtos amplificados}

A endonuclease de restrição Sma I foi utilizada para confirmar a especificidade dos produtos amplificados por PCR com os oligonucleotideos iniciadores LTI e LTII, enquanto a enzima Ava II foi utilizada para digerir as amplificações de STI e STII. Para este teste, a reação de amplificação por PCR foi realizada em um volume final de $50 \mathrm{~mL}$. A reação de amplificação foi precipitada com acetato de sódio e etanol absoluto gelado e incubada a $-20^{\circ} \mathrm{C}$ por 1 hora. Após, o DNA foi precipitado por centrifugação a 15.493 g por 20 minutos e re-suspendido em $10 \mathrm{~mL}$ de TE. A reação de digestão foi preparada em um volume final de $20 \mathrm{~mL}$, contendo $10 \mathrm{~mL}$ do produto da reação de PCR ( 400ng de DNA), tampão para enzima 1X, $5 \mathrm{U}$ da enzima de restrição e água Milli-Q estéril para completar o volume. A mistura foi incubada em banho de água conforme indicação do fabricante.

\section{Eletroforese e visualização do DNA}

Os produtos de amplificação e das digestões foram resolvidos em gel de agarose $1,2 \%$ e $2,0 \%$ respectivamente. Os géis foram fotografados com uma máquina Kodak DC 12.1 versão 3.5.2.

\section{RESULTADOS}

No processo de isolamento utilizando o meio seletivo EMB para isolamento E. coli, foram isoladas um total de 71 colônias que apresentaram características morfológicas semelhantes àquelas de E. coli. Estes isolados foram identificados, através de provas bioquímicas e 36 confirmaram os testes para E. coli. 
Os ensaios de PCR realizados para avaliar a especificidade dos oligonucleotídeos iniciadores apresentaram resultados satisfatórios para a detecção dos microrganismos alvo. Os oligonucleotídeos iniciadores desenhados para os genes LT e ST amplificaram produtos específicos e com o tamanho esperado de $221 \mathrm{pb}$ e $167 \mathrm{pb}$, respectivamente. No entanto, houve reações cruzadas entre $E$. coli e Shigella sp para ambas as toxinas.

O teste de sensibilidade da reação de PCR revelou ser necessário no mínimo $10^{4} \mathrm{UFC} / \mathrm{mL}$ de $E$. coli na amostra para estas serem detectadas. Esta concentração foi necessária, na utilização dos oligonucleotídeos iniciadores STI e STII (Figura 1), como nos pares LTI e LTII (Figura 2). Ainda, as amostras padrão de E. coli mostraram apresentar os genes ST e LT no genoma da célula, porém a sensibilidade foi menor do que para o DNA plasmideal, $10^{6}$ e $10^{5} \mathrm{UFC} / \mathrm{mL}$ respectivamente.

A concentração mínima de ácidos nucléicos purificados, de E. coli, necessários para a detecção dos genes ST e LT na reação de PCR foram de $10 \mathrm{fg} /$ $\mathrm{mL}$ e $0,1 \mathrm{fg} / \mathrm{mL}$ de DNA plamideal respectivamente (Figuras 3 e 4 ).

Dos 36 isolados identificados como sendo $E$. coli, somente cinco foram positivos para o teste de virulência através de PCR. As cinco linhagens são procedentes de um mesmo ponto de coleta, sendo três delas $\mathrm{LT}^{+} \mathrm{ST}^{-}$e duas $\mathrm{LT}^{+} \mathrm{ST}^{+}$. Não foi detectada a presença de E. coli enterotoxigênica quando o PCR foi aplicado diretamente nas amostras brutas de esgoto.

A especificidade dos produtos de amplificação do PCR foi confirmada através das endonucleases de restrição Sma I e Ava II que produziram os fragmentos de tamanho esperado para E. coli. Os produtos de STI e STII (167 pb) formaram fragmentos de $60 \mathrm{pb}$ e $107 \mathrm{pb}$ quando digeridos com Ava II, enquanto os produtos da amplificação cruzada de Shigella sp. apresentaram fragmentos de tamanhos distintos daqueles da E. coli. Os produtos de LTI e LTII (221 $\mathrm{pb}$ ) formaram fragmentos de $70 \mathrm{pb}$ e $151 \mathrm{pb}$ quando digeridos por Sma I, a qual não digeriu os produtos de amplificação cruzada de Shigella sp. (dados não apresentados).

\section{DISCUSSÃO}

A E. coli foi isolada em todas as amostras de esgoto analisadas, porém, com baixa frequiência. Este representante da família enterobacteriaceae faz parte da flora gastrointestinal de humanos e animais, mas fisiologicamente é versátil e pode adaptar-se bem se tornando apta a colonizar habitats extraintestinais [25]. No entanto, se competidores estão presentes no meio

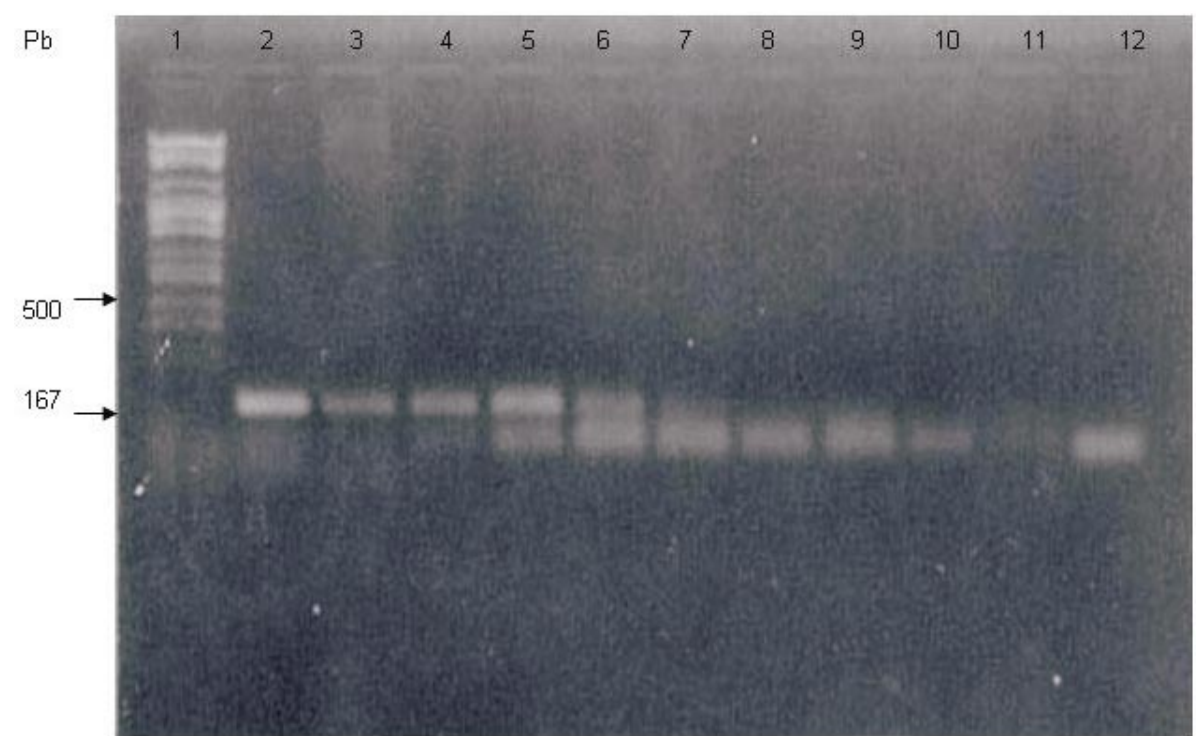

Figura 1. Eletroforese em gel de agarose $1,2 \%$ corado com brometo de etídeo com os resultados do ensaio de sensibilidade quanto ao número de UFC/mL realizado com o DNA plasmideal e o par de oligonucleotídeos iniciadores STI e STII. (1) Maçador de peso molecular $\lambda$ digerido com Hind III, Eco RI e Cla I.; (2) $10^{9} \mathrm{UFC} / \mathrm{mL}$; (3) $10^{8} \mathrm{UFC} / \mathrm{mL}$; (4) $10^{7} \mathrm{UFC} / \mathrm{mL}$; (5) $10^{6} \mathrm{UFC} / \mathrm{mL}$; (6) $10^{5} \mathrm{UFC} / \mathrm{mL}$; (7) $10^{4} \mathrm{UFC} / \mathrm{mL}$; (8) $10^{3} \mathrm{UFC} / \mathrm{mL}$; (9) $10^{2} \mathrm{UFC} / \mathrm{mL}$; (10) $10^{1} \mathrm{UFC} / \mathrm{mL}$; (11) $10^{0} \mathrm{UFC} / \mathrm{mL}$; (12) controle. 


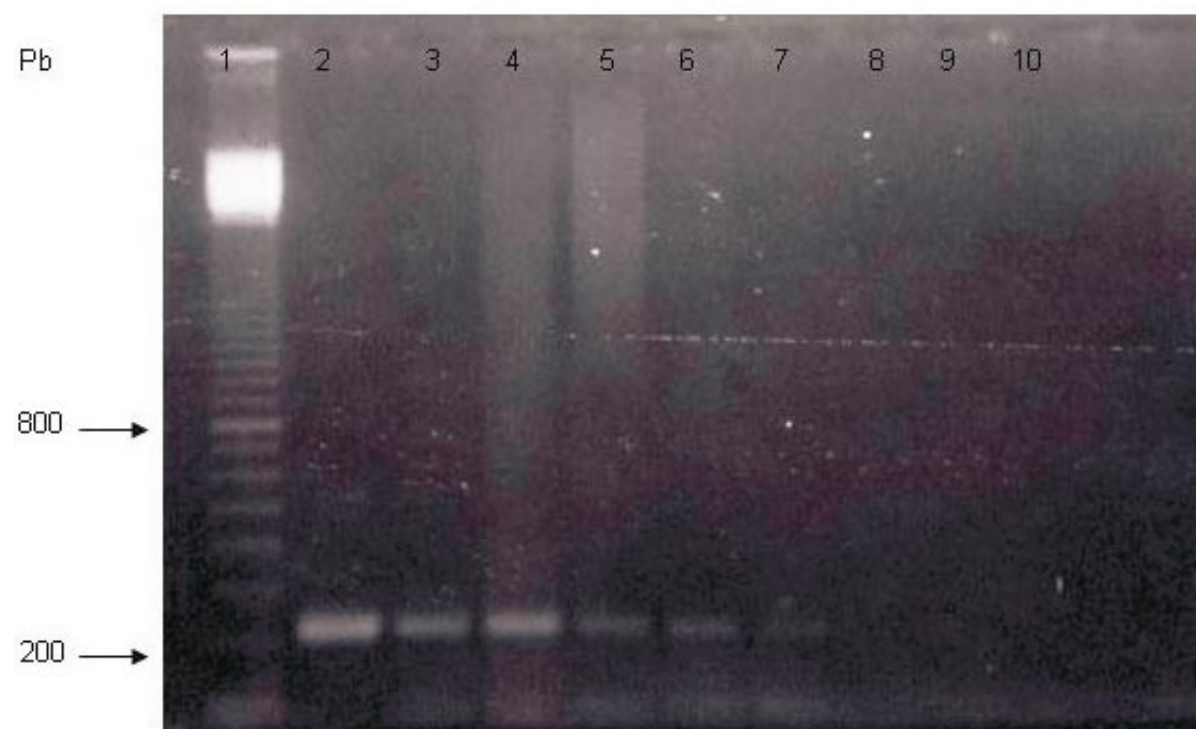

Figura 2. Eletroforese em gel de agarose 1,2\% corado com brometo de etídeo com os resultados do ensaio de sensibilidade quanto ao número de UFC/mL realizado com o DNA plasmideal e o par de oligonucleotídeos iniciadores LTI e LTII. (1) Maçador de peso molecular Ladder 100pb; (2) $10^{9} \mathrm{UFC} / \mathrm{mL}$; (3) $10^{8} \mathrm{UFC} / \mathrm{mL}$; (4) $10^{7} \mathrm{UFC} / \mathrm{mL}$; (5) $10^{6} \mathrm{UFC} / \mathrm{mL}$; (6) $10^{5} \mathrm{UFC} / \mathrm{mL}$; (7) $10^{4} \mathrm{UFC} / \mathrm{mL}$; (8) $10^{3} \mathrm{UFC} / \mathrm{mL}$; (9) $10^{2} \mathrm{UFC} / \mathrm{mL}$; (10) controle.

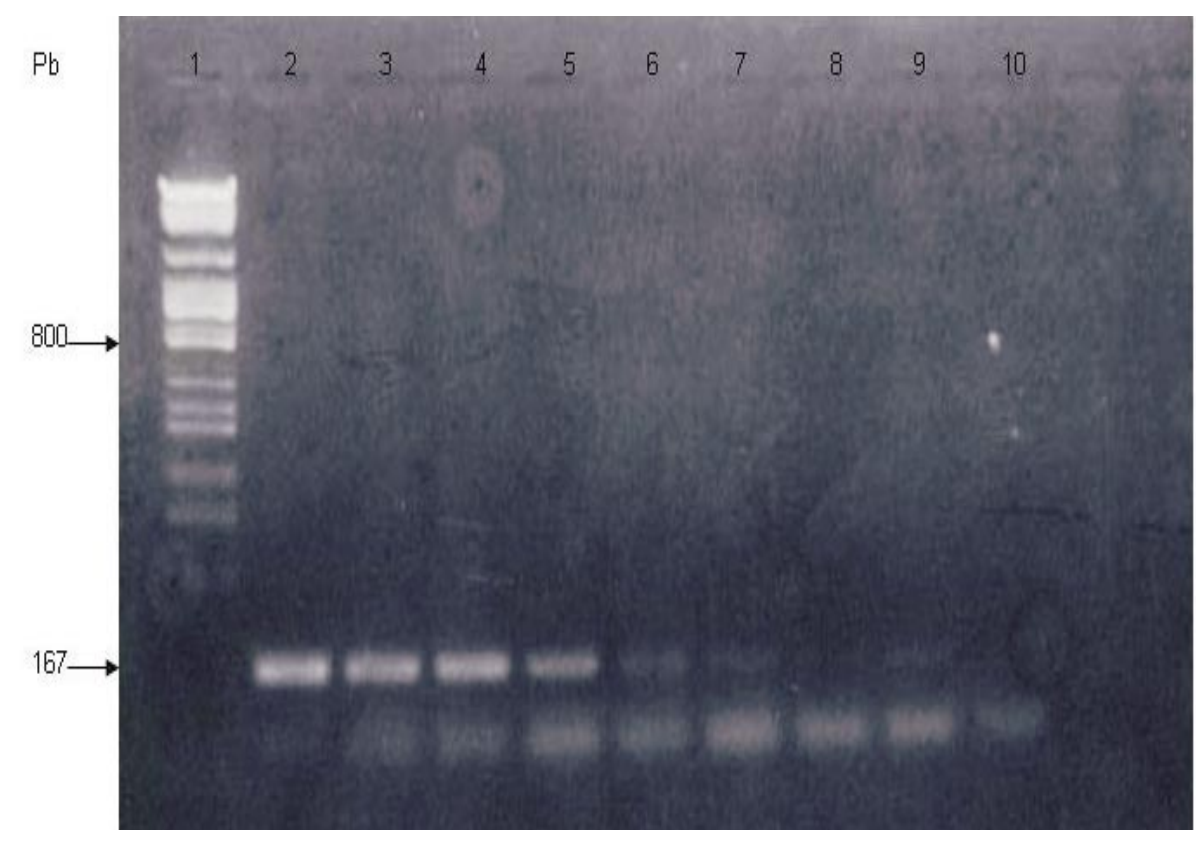

Figura 3. Eletroforese em gel de agarose 1,2\% corado com brometo de etídeo com os resultados do ensaio de sensibilidade quanto ã concentração de ácidos nucléicos realizado com o DNA plasmideal e o par de oligonucleotídeos iniciadores STI e STII. (1) Maçador de peso molecular $\lambda$ digerido com Hind III, Eco RI e Cla I.; (2) $50 \mathrm{ng}$; (3) $10 \mathrm{ng}$; (4) $1 \mathrm{ng}$; (5) 0,1ng; (6) 10 pg; (7)1 pg; (8) 0,1 pg; (9) 10 fg ; (10) 1 fg; (11) controle.

aquático, pode ser constatado um rápido declínio na contagem de E. coli. Isso é atribuído à inabilidade desse microrganismo em competir, com sucesso, por nutrientes com outras bactérias presentes no ambiente [11].

As Shigella sp. e E. coli são microrganismos intimamente relacionados [12] que compartilham genes para virulência codificados por plasmídeos [9,15,17]. Os resultados obtidos neste trabalho condizem com os da bibliografia, sugerindo haver homologia genética entre estes dois gêneros. Os oligonucleotídeos iniciadores desenhados para cada gene amplificaram produtos específicos e de tamanho esperado. Porém, as amplificações inespecíficas não foram completa- 


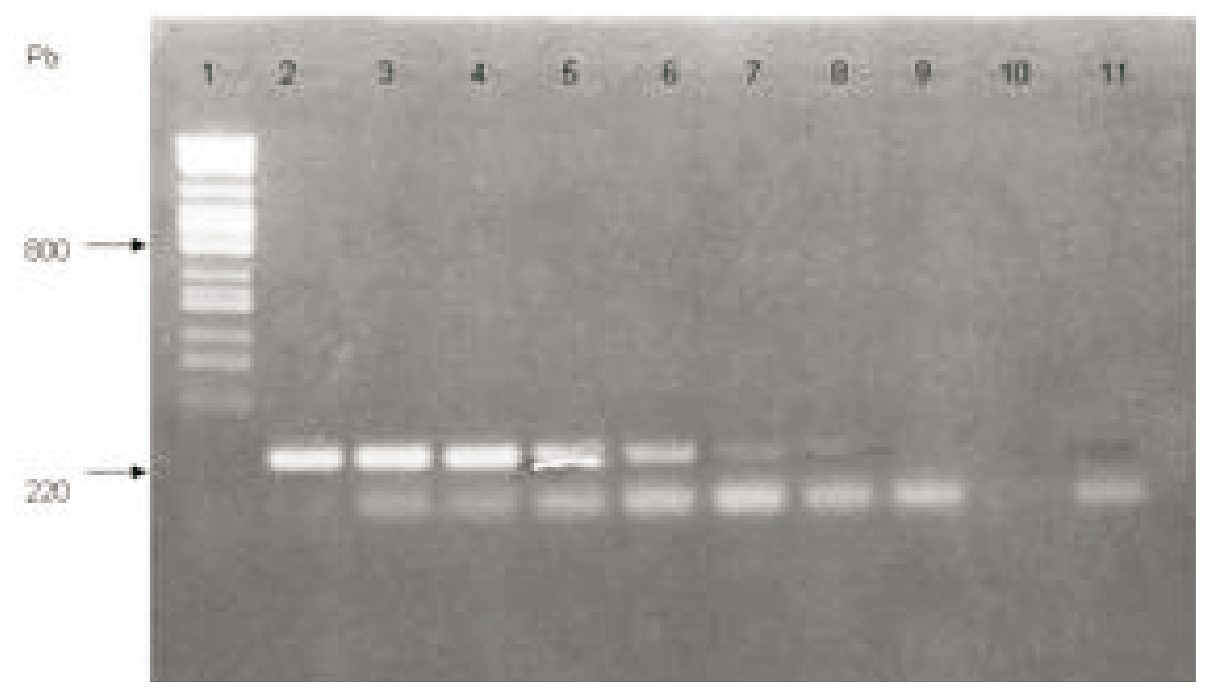

Figura 4. Eletroforese em gel de agarose 1,2\% corado com brometo de etídeo com os resultados do ensaio de sensibilidade quanto à concentração de ácidos nucléicos realizado com o DNA plasmideal e o par de oligonucleotídeos iniciadores LTI e LTII. (1) Maçador de peso molecular $\lambda$ digerido com Hind III, Eco RI e Cla I.; (2) 50ng; (3) 1ng; (4) 0,1ng; (5) $1 \mathrm{pg}$; (6) 0,1 pg; (7) $1 \mathrm{fg}$; (8) $0,1 \mathrm{fg}$; (9) $10 \mathrm{fn}$; (10) $1 \mathrm{fn}$; (11) controle.

mente eliminadas, e as reações cruzadas entre $E$. coli e Shigella sp. permaneceram evidentes. No entanto, após a digestão com enzima de restrição os padrões produzidos foram diferentes. Sansonetti et al. [20] mostraram através de experimentos de hibridização que plasmídeos presentes Shigella sp. e E. coli possuem sequiências homólogas. Da mesma forma, os autores demonstraram que o uso de enzimas de restrição revelava uma completa falta de relação no padrão dos fragmentos produzidos. Sansonetti et al. [20] também sugerem que essas moléculas plasmideais podem ter derivado de uma molécula ancestral comum que sofreu alterações evolucionárias nos sítios de restrição.

Com a reação de PCR foram detectados cinco isolados com potencial virulento entre as 36 identificadas bioquimicamente como E. coli. Porém, não foi detectada a presença de $E$. coli enterotoxigênica quando o PCR foi aplicado diretamente nas amostras de esgoto bruto. A análise dos resultados sugere duas interpretações quanto a não detecção de $E$. coli enterotoxigênica diretamente das amostras de esgoto: a) os microrganismos estavam em uma concentração abaixo do limite mínimo que as condições de amplificação usadas eram capazes de detectar; b) houve uma interferência de substâncias que inibiram a reação de PCR e que não foram totalmente eliminadas com o método de filtração e extração de DNA aplicados. A concentração de impurezas ambientais, tais como, ácidos húmicos, agentes quelantes, detergentes e metais pesados podem contribuir para a inibição da reação, diminuindo a sensibilidade da técnica quando aplicada em amostras ambientais [26]. Tsai et al. [27] alcançaram alta sensibilidade com a técnica de PCR, chegando a uma detecção de 3ng DNA/reação após o uso de uma coluna de Sephadex. Nenhum produto havia sido detectado quando extratos de DNA não purificados foram usados para a amplificação. TamanaiShacoori et al. [24] obtiveram um limite de detecção de $1 \mathrm{UFC} / \mathrm{mL}$ de água não tratada utilizando a filtração como método de purificação e concentração da amostra bruta. Portanto, a presença de patógenos pode ser subestimada quando os contaminantes não são eliminados completamente da amostra ambiental.

Os métodos bacteriológicos de cultura, utilizados neste trabalho, permitiram o isolamento de $E$. coli presentes nas amostras de esgoto. No entanto, o uso apenas dos testes bioquímicos não se pode indicar o potencial de virulência destes microrganismos. As técnicas baseadas em PCR permitem a identificação dos microrganismos patogênicos além, de reduzir o tempo de detecção em relação ao bioquimismo. Segundo alguns autores a maior rapidez na detecção de microrganismos obtida através do PCR, não necessariamente significa uma maior sensibilidade, quando este é comparado com métodos de cultura clássicos, os quais utilizam etapas de enriquecimento das amostras [3].

A sensibilidade para a detecção de microrganismos através do PCR depende das condições de 
amplificação. Aumentando-se a temperatura de anelamento, aumenta-se a especificidade da amplificação para as células alvo, porém isso pode diminuir a sensibilidade de detecção [2]. Para alguns autores o uso de técnicas para detecções rápidas, como, por exemplo, sondas de DNA ou RNA, imunoensaios enzimáticos e PCR são ainda deficientes, principalmente quanto à sensibilidade. Os autores sugerem um pré-enriquecimento não seletivo e enriquecimento seletivo das amostras [27]. Essa seria uma alternativa necessária para a detecção de baixas concentrações de microrganismos, de células estressadas e diminuição da interferência de compostos inibitórios que afetam a reação de amplificação [27]. O procedimento de enriquecimento não foi realizado neste trabalho, pois o objetivo era utilizar o ensaio de PCR para detectar a E. coli (ETEC) na concentração em que estas se apresentavam na amostra, testando, desta forma, a sensibilidade da técnica, nas condições utilizadas, para baixas concentrações de microrganismos.

Quando combinados os procedimentos de cultivos e testes rápidos o número de resultados positivos pode aumentar significativamente, reduzindo assim os falsos negativos [23].

As enzimas de restrição utilizadas foram específicas, para a confirmação dos produtos de amplifi- cação obtidos dos microrganismos padrão e dos isolados de esgoto. As amplificações cruzadas entre $E$. coli enterotoxigênica e Shigella sp. sugerem haver homologia genética entre estes microrganismos, mas os diferentes padrões de clivagem resultantes da digestão dos produtos de Shigella sp. indicam que os genes das toxinas termo-lábil e termo-estável não são compartilhados por esse gênero.

\section{CONCLUSÕES}

Os protocolos de PCR desenvolvidos neste trabalho com os oligonucleotídeos iniciadores STI e STII, LTI e LTII, podem auxiliar na detecção de $E$. coli enterotoxigênica em amostras de água de esgoto. Deve-se considerar uma diminuição no nível de sensibilidade do método quando a amostra ambiental não for totalmente livre de impurezas que possam interferir no processo de amplificação. A confirmação dos resultados do PCR através de digestão com as enzimas de restrição Sma I e Ava II, eliminou resultados falsos positivos quando da ocorrência de reações cruzadas entre E. coli enterotoxigênica e Shigella spp. O tempo utilizado neste processo deve ser considerado como um benefício na obtenção de diagnósticos de contaminação da água. Além disso, o PCR avaliou o potencial genotípico do microrganismo para a virulência.

\section{REFERÊNCIAS}

1 Alexander T.J.L. 1994. Neonatal diarrhea in pigs. In Gyle C.L.(Ed). E.coli in domestic animals and humans. Willingfrod: CAB International, pp.151-170.

2 Bej A.K., Steffan R.J., Dicesare J., Haff L. \& Atlas R.M. 1990. Detection of coliform bacteria in water by polymerase chain reaction and gene probe. Applied and Environmental Microbiology. 56: 307-314.

3 Bej A.K., Mahburani M.H., Boyce M.J. \& Atlas R.M. 1994. Detection of Salmonella spp. in oysters by PCR. Applied and Environmental Microbiology. 60: 368-373.

4 Berderov E.M., Zhou Y., Francis D.H., Scott M.A., Kachman S.D. \& Moxley R.A. 2004. Relative importance of heat-labile enterotoxin in the causation of severer diarrheal disease in the gnotob iotic piglet model by a strain of enterotoxigenic $E$. coli that produces multiple enterotoxins. Infected Immunology. 72: 3914-3924.

5 Bollela V.R., Sato D.N. \& Fonseca B.A.L. 1999. Problemas na padronização da reação em cadeia da polimerase para diagnósticos da tuberculose pulmonar. Revista de Saúde Pública. 33: 281-286.

6 Cohen N.D., Neibergs H.L. \& Wallis D.E. 1994. Genus - specific detection of Salmonella in equine feces by use of the polymerase chain reaction. American Journal of Veterinary Research. 55: 1049-1054.

7 Dwarakata P., Visweswariah S.S., Subrahmanyam Y.V.B.K., Shanthi G., Jagnnatha H.M. \& Balganesh T.S. 1989. Cloning and hyperexpression of a gene encoding the heat-stable toxin of Escherichia coli. Gene. 81: 219-226.

8 Evans Jr. D. \& Evans D.G. 1993. Medmicro. Escherichia coli in diarrheal disease. 11p. Disponível em: <http://www. gsbsutmb.edu/microbook/ch025.htm>. Acessado em 11/1998.

9 Lan R., Lumb B., Ryan D. \& Reeves P.R. 2001. Molecular evolution of large virulence plasmid in Shigella clonesand enteroinvasive Escherichia coli. Infection and Immunity. 69: 6303-6309.

10 Leyten E.M.S., Soonawala D., Schultsz C., Herzog C., Ligthelm R.J., Wijnands S. \& Visser L. 2005. Analysis of efficacy of CVD 103-HgR live oral cholera vaccine again travellers' diarrhoea in a randomised, double-blind, placebo-controlled study. Vaccine. 43: 5120-5126. 
11 Lim C.H. \& Flint K.P. 1989. The effects of a nutrient on the survival of Escherichia coli in lake water. Journal of Applied Bacteriology. 66: 559-569.

12 Mahon C. \& Manuselis Jr.G. 1995. Text book of diagnostic microbiology. 2nd edn. Columbus: W.B. Saunders Company, $1076 \mathrm{p}$.

13 Martins M.T., Rivera I.G., Clark D.L. \& Olson B.H. 1992. Detection of virulence factors in culturable Escherichia coli isolates from water samples by DNA probes and recovery of toxin - bearing strains in minimal o-nitrophenol-b-D-galactopyranoside4-methylumbelliferyl-b-D-glucuronide media. Applied and Environmental Microbiology. 58: 3095-3100.

14 McFaddin J.F. 2000. Biochemical test for identification of medical bacteria. 3rd edn. Philadelphia: The Williams \& Wilkins, $312 \mathrm{p}$.

15 Ochman H., Whittam T.S., Caugant D.A. \& Selander R.K. 1983. Enzyme polymorphism and genetic population structure in Escherichia coli and Shigella. Journal of General Microbiology. 129: 2715-2726.

16 Ozerol I.H., Bayraktar M.R., Iseri L., Otlu B. \& Durmaz R. 2005. The prevalence and molecular typing of enterotoxigenic Escherichia coli strains isolated from diarrheic stools in Malatya, Turkey. New Mocrobiology. 28: 237-243.

17 Pupo G.M., Karaolis D.K.R., Lan R. \& Reeves P.R. 1997. Evolutionary relationships among pathogenic and non-pathogenic Escherichia coli strains inferred from multilocus enzyme electrophoresis and $m d h$ sequence studies. Infection and Immunity. 65: 2685-2692.

18 Regua-Mangia A.H., Gomes T.A.T., Vieira M.A.M., Andrade J.R.C., Irino K. \& Teixeira L.M. 2004. Frequency and characteristics of a diarrhoeagenic Escherichia coli strains isolated from children with and without diarrhoea in Rio de Janeiro, Brazil. Journal of Infection. 48: 161-167.

19 Sambrook J., Fritsch E.F. \& Maniatis T. 1989. Molecular cloning: A laboratory manual. 2nd edn. New York: Cold Spring Harbor Laboratory, 1355p.

20 Sansonetti P.J., d'Hauteville H., Ecobichon C. \& Pourcel C. 1983. Molecular comparison of plasmid in Shigella and enteroinvasive Escherichia coli. Annals of Microbiology. 134A: 295-318.

21 Shaheen H.I., Khalil S.B., Rao M.R., Elyazeed R.A., Wierzba T.F., Peruski L.F., Putnam S., Navarro A., Morsy B.Z., Cravioto A., Clemens J.D., Svennerholm A.M. \& Savarino S. 2004. Phenotypic profiles of enterotoxigenic Escherichia coli associated with early childhood diarrhea in rural Egypt. Journal of Clinical Microbiology. 42: 5588-5595.

22 So M., Heffron F. \& McCarthy B.J. 1979. The E. coli gene encoding heat stable toxin is a bacterial transposon flanked by inverted repeats of IS 1. Nature. 277: 453-456.

23 Stone G.G., Oberst R.D., Hays M.P., McVey S., Chenagappa M.M. 1994. Detection of Salmonella sorovars from clinical samples by enrichment broth cultivation - PCR procedure. Journal of Clinical Microbiology. 32: 1742-1749.

24 Tamanai-Shacoori Z., Jolivet-Gougeon T.S., Pommeruy M., Cormier M. \& Colwell R.R. 1994. Detection of enterotoxigenic Escherichia coli in water by polymerase chain reaction amplification and hybridization. Canidian Journal of Microbiology. 40: 243-249.

25 Kenneth Todar University of Wisconsin. 2002. Medison Department of Bacteriology. Todar's Online Textbook of bacteriology: Pathogenic E. coli, 8p. Disponível em: <http://www. textbookofbacteriology.net/e.coli.html>. Acessado em 01/2002.

26 Trevors J.T. \& Van Elsas J.D. 1995. Nucleic acids in the environment methods and applications: introduction to nucleic acids in the environment. Berlin: Springer-Verlag, 260p.

27 Tsai Y-L., Palmer C.J. \& Sangermano L.R. 1993. Detection of Escherichia coli in sewage and sludge by polimerase chain reaction. Applied and Environmental Microbiology. 59: 353-357.

28 Yamamotto T. \& Yokota T. 1983. Sequence of heat-lable enterotoxin of Escherichia coli pathogenic for humans. Journal of Bacteriology. 2: 728-733.

29 Zhu Q., Lim C.K. \& Chan Y.N. 1996. Detection of Salmonella typhi by polymerase chain reaction. Journal of Applied Bacteriology. 80: 244-251.

30 Zhang W., Berberov E., Freeling J., He D., Moxley R. \& Francis D.H. 2006. Significance of heat stable and heat-labile enterotoxins in porcine colibacillosis in an additive model for pathogenicity study. Infection Immunology. 76: 3107-3114.

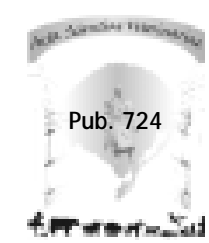

